\title{
Direct detection of Marek's disease virus in poultry dust by loop-mediated isothermal amplification
}

\author{
Grzegorz Woźniakowski • \\ Elżbieta Samorek-Salamonowicz
}

Received: 9 March 2014 / Accepted: 19 June 2014/Published online: 2 July 2014

(C) The Author(s) 2014. This article is published with open access at Springerlink.com

\begin{abstract}
Marek's disease virus (MDV) is a serious concern for poultry production and represents a unique herpesvirus model. MDV can be shed by doubly infected chickens despite vaccination. The fully infectious MDV particles are produced in the feather follicle epithelium (FFE), and MDV remains infectious for many months in fine skin particles and feather debris. Molecular biology methods including PCR and real-time PCR have been shown to be valuable for the detection of MDV DNA in farm dust. Recently, loop-mediated isothermal amplification (LAMP) was found to be useful in the detection of MDV in feathers and internal organs of infected chickens. LAMP is also less affected by the inhibitors present in DNA samples. Taking into account the advantages of LAMP, direct detection of MDV DNA in poultry dust has been conducted in this research. The detection of MDV DNA was possible in 11 out of the 12 examined dust samples without DNA extraction. The DNA was retrieved from dust samples by dilution and incubation at $95{ }^{\circ} \mathrm{C}$ for $5 \mathrm{~min}$. The direct detection of MDV DNA in the dust was possible within $30 \mathrm{~min}$ using a water bath and UV light. The results were confirmed by electrophoresis and melting curve analysis of the LAMP products. Our results show that LAMP may be used to test for the presence of virulent MDV in poultry farm dust without DNA extraction.
\end{abstract}

Keywords Marek's disease virus - Poultry dust - Direct detection $\cdot$ Loop-mediated isothermal amplification

G. Woźniakowski $(\bowtie) \cdot$ E. Samorek-Salamonowicz Department of Poultry Viral Diseases, National Veterinary Research Institute, Partyzantów 57 Avenue, 24-100 Puławy, Poland

e-mail: grzegorz.wozniakowski@piwet.pulawy.pl
Marek's disease virus (MDV; species Gallid herpesvirus 2, genus Mardivirus, family Herpesviridae [5, 21]) is one of the most contagious agents in poultry production. Consequently, Marek's disease (MD) has a huge economic impact $[15,17,22,25]$. Recently, increasing incidence of MD caused by virulent MDV strains with increased pathogenicity has been observed [2, 8, 22, 25, 27]. Initially, MDV that is present in poultry farm dust infects the host via the respiratory tract $[5,13,21]$. The virus is then transferred by the bloodstream in alveolar macrophages to $\mathrm{B}$ and $\mathrm{T}$ lymphocytes. After the primary infection stage, between 7 and 14 days postinfection (dpi), MDV may become latent in infected lymphoid cells [5], which proliferate in different parts of host, especially in the liver, spleen, kidney, proventriculus and ovaries. This leads to tumour formation after reactivation of the virus to the transformation stage $[17,21]$. Most MDV transmission occurs in the fully productive stage of infection and takes place in the feather follicle epithelium (FFE) $[5,7,12,19]$. Subsequently, the virus is then transferred to the environment as fine particles of skin and feather debris $[3,4,7,11]$. The DNA of MDV can be detected in poultry dust as early as 7 dpi $[3,4,11]$. Infectious MDV can persist in dust particles for many months and therefore be a potential source of infection for the next flock of chickens. Vaccination against MD with live attenuated vaccines safeguards against its clinical form as well as against tumours [21, 25]. However, this does not exclude the possibility of superinfection with very virulent MDV (vvMDV) and shedding of the virus into the environment [5]. Poultry farm dust may be also a good source of MDV DNA in order to monitor any possible future outbreak of infection in the flock following decontamination of an affected farm [7, 11, 13, 19, 22].

Conventional detection methods of viral DNA in dust such as polymerase chain reaction (PCR) and real-time 
PCR require the extraction of nucleic acids $[3,4,6,9-12$, 19, 22-24]. PCR-based techniques are dependent on laboratory equipment, including thermocyclers or complex real-time PCR systems. Recently, loop-mediated isothermal amplification (LAMP) has been described as a powerful and rapid tool for MDV detection in infected chickens $[1,26]$. LAMP partially fulfils expectations as an ideal diagnosis method because it can be used without access to advanced laboratory equipment $[16,18]$. The bottleneck in the LAMP procedure is the extraction of nucleic acid.

The objective of this study was to apply the LAMP method for direct detection of MDV in poultry farm dust without DNA purification from crude samples. This is the first report of a LAMP application used for the monitoring of MDV in poultry farm dust.

The standard 31/07 vv+MDV strain (GenBank accession number HQ204806.1) with a titer of $10^{4.1} \mathrm{TCID}_{50}$ (8812 PFU) was used as positive control for the MDV LAMP. The strain was propagated in SPF chicken embryo fibroblasts (CEFs). The stock of the 31/07 strain was stored in liquid nitrogen at $\left(-196{ }^{\circ} \mathrm{C}\right)$. The DNA of the $31 / 07$ strain was extracted from $200 \mu \mathrm{L}$ of the virus stock using a QIAamp Mini Kit (QIAGEN, Hilden, Germany) as described previously [27].

Dust samples (about $20 \mathrm{~g}$ each) were collected from twelve different farms where MD had previously been diagnosed in chickens vaccinated with FC126 HVT and CVI988/Rispens. The dust from the farms was collected into plastic sealed bags, mainly from air fans, window sills and floors. The dust from each farm was then pooled, and the dust samples were then stored at $-20{ }^{\circ} \mathrm{C}$ for further examination. About $20 \mathrm{mg}$ of each pooled dust sample was resuspended in $480 \mu \mathrm{l}$ of phosphate-buffered saline (PBS) by vigorous vortexing in a $1.5-\mathrm{ml}$ Eppendorf ${ }^{\circledR}$ tube. The samples were incubated for $5 \mathrm{~min}$ at $95{ }^{\circ} \mathrm{C}$ and then centrifuged at $6000 \times \mathrm{g}$ for $3 \mathrm{~min}$ (Mikro 22R, Hettich Zetrifugen, Tuttlingen, Germany). The supernatants were then transferred to fresh microtubes and diluted 10-fold in PBS. The DNA yield and purity were measured by determining the $\mathrm{A}_{260} / \mathrm{A}_{280}$ ratio using a Nanophotometer ${ }^{\mathrm{TM}}$, P-Class (Implen, Westlake Village, CA, USA). Three pairs of primers complementary to the meq gene sequence of the RB1B very virulent plus MDV strain (GenBank accession number AY571783) were designed using Primer Explorer version 4 (NetLaboratory, Tokyo, Japan) (Table 1) [26]. The reactions were set up on ice in 0.2-ml OptiAmp ${ }^{\circledR}$ optical tubes (Applied Biosystems, Foster City, CA, USA). The LAMP volume was $15 \mu \mathrm{L}$ and contained $7.5 \mu \mathrm{L}$ of Isothermal Mastermix (OptiGene, Horsham, West Sussex, United Kingdom), 50 pmol each of inner primers FIP and BIP, 10 pmol each of outer primers F3 and B3, 25 pmol each of loop primers LF and LB, $1 \mu \mathrm{l}$ of 1:10,000-diluted ROX passive reference dye (EurX, Gdansk, Poland), $1 \mu \mathrm{l}$
Table 1 Sequences of LAMP primers used for detection of MDV-1 in dust samples

\begin{tabular}{ll}
\hline Primer & Sequence $\left(5^{\prime}-3^{\prime}\right)$ \\
\hline F3 & TTCCCTCTTCTGCCCTCC \\
B3 & TCCTGTTCGGGATCCTCG \\
FIP & GTAAACCGTCCCCGGCGATG \\
& TTTTGGGCATCTTCCCTGCATTG \\
BIP & CTTTGTCCTGTTGGCCAGGCTC \\
& TTTTGACGAGCATAAAGCCTCTCC \\
LF & TACACGGCTCGGTAACAGGA \\
LB & CCACATCCGGCTCCGGAGCC \\
\hline
\end{tabular}

TTTT is a thymidine linker in the FIP and BIP primers

The primers were designed based on the meq gene sequence of the RB1B very virulent plus MDV strain (GenBank accession number AY571783), using Primer Explorer version 4 (NetLaboratory, Tokyo, Japan)

of PCR-grade water (EurX, Gdansk, Poland) and $2 \mu \mathrm{l}$ of DNA template. After incubation of the reaction mixtures in a water bath (Memmert, Schwabach, Germany) at $62.3{ }^{\circ} \mathrm{C}$ for $30 \mathrm{~min}, 0.5 \mu \mathrm{l}$ of a 1:100 stock dilution of 10,000 -fold concentrated SYBR Green I dye in DMSO (Invitrogen) was added to each sample. The samples were observed under UV illumination to detect green fluorescence in positive samples. At the same time, the reaction was run in an ABI 7500 system (Applied Biosystems, Foster City, CA, USA) at $62.3{ }^{\circ} \mathrm{C}$ for 40 cycles ( 1 min each). Next, melting curve analysis was conducted at temperatures ranging from $95{ }^{\circ} \mathrm{C}$ to $60.0{ }^{\circ} \mathrm{C}$. The positive control was DNA from the 31/07 strain, and the negative control DNA was extracted from uninfected CEFs. Pictures were taken using a G5 camera (Canon, Ōta, Tokyo, Japan). The cycle threshold values $\left(\mathrm{C}_{\mathrm{T}}\right)$ were recorded and melting curve analysis was done using the software from the ABI 7500 system (version 2.0.1). LAMP amplicons were separated in $2 \%$ agarose gels stained with GelRed ${ }^{\mathrm{TM}}$ dye (Biotum, Hayward, CA, USA).

In this study, we describe the first direct detection of MDV in crude dust samples using LAMP. The previously described application of LAMP for MDV DNA detection was conducted using samples extracted from feather tips using commercial kits or phenol-chloroform based procedures [26]. Over the past few years, LAMP has been found to be a powerful method for detecting a number of viral pathogens of poultry and free-ranging birds [1, 18, 26]. However, the application of an inexpensive method for infarm detection of viral genetic material has been limited by the necessity of obtaining purified nucleic acids $[16,18]$. Therefore, the development of a 'portable' technique that can be used even when access to laboratory equipment is limited has not been fully accomplished. The DNA polymerases used for LAMP include Bsm, Bst, GspSSD 
polymerase $[1,16,26]$. The last of these has been known to be less prone to inhibition than the other. Therefore, we decided to examine whether the simple process of dilution

Table 2 Detection of MDV DNA in dust samples by LAMP

\begin{tabular}{lllc}
\hline Sample & $\begin{array}{l}\text { DNA purity } \\
\mathrm{A}_{260} / \mathrm{A}_{280} \text { ratio/ } \\
\text { concentration } \\
(\mathrm{ng} / \mu \mathrm{L})\end{array}$ & $\begin{array}{l}\text { Ct value } \\
\text { LAMP } \\
\text { MDV-1 }\end{array}$ & $\begin{array}{l}\text { Melting } \\
\text { temperature }\end{array}$ \\
\hline Negative control & $1.83 / 125.0$ & 40.0 & - \\
Farm 1 & $0.47 / 24.3$ & 30.4 & 87.4 \\
Farm 2 & $0.38 / 15.9$ & 18.3 & 86.9 \\
Farm 3 & $0.41 / 19.0$ & 21.4 & 86.8 \\
Farm 4 & $0.42 / 20.5$ & 15.4 & 87.4 \\
Farm 5 & $0.45 / 27.5$ & 40.0 & - \\
Farm 6 & $0.41 / 19.9$ & 16.7 & 86.9 \\
Farm 7 & $0.45 / 20.1$ & 20.5 & 87.4 \\
Farm 8 & $0.41 / 19.4$ & 20.7 & 87.3 \\
Farm 9 & $0.39 / 7.9$ & 14.0 & 86.5 \\
Farm 10 & $1.0 / 12.7$ & 20.9 & 86.8 \\
Farm 11 & $0.46 / 18.4$ & 17.0 & 87.1 \\
Farm 12 & $0.40 / 10.5$ & 15.9 & 86.3 \\
Positive control DNA & $1.85 / 200.5$ & 11.8 & 87.4 \\
of 31/07 MDV strain & & & \\
\hline
\end{tabular}

The measured DNA purity ratio $\left(\mathrm{A}_{260} / \mathrm{A}_{280}\right)$, concentration $(\mathrm{ng} / \mu \mathrm{L})$, cycle threshold value and melting temperature of LAMP products are given. Negative control, DNA extracted from uninfected SPF chicken embryo fibroblasts (CEFs) and heat treatment of dust samples from MDV-contaminated farms would be sufficient to perform LAMP using GspSSD polymerase. Indeed, by dilution and incubation at $95{ }^{\circ} \mathrm{C}$ of dust samples collected from 12 different chicken farms, it was possible to retrieve from 7.9 to $27.5 \mathrm{ng}$ of DNA per $\mu \mathrm{L}$. However, the crude samples appeared to contain protein contamination, since the $\mathrm{A}_{260} / \mathrm{A}_{280}$ ratio ranged from 0.38 to 1.0 (Table 2). In spite of this, the LAMP was found to be resistant to contamination, as we obtained a positive signal for MDV, visible as green fluorescence in 11 out of 12 dust samples (Fig. 1). The one negative dust sample that was obtained was also extracted using a commercial DNA extraction kit. However in spite of this, the sample remained MDV negative, possibly due to the presence of inhibitors. Indeed, attempts to amplify MDV DNA from dust samples using conventional PCR also failed (data not shown). The reliability of the results was confirmed by the $C_{T}$ values in the ABI 7500 system (Table 2) as well as gel electrophoresis and melting curve analysis (Fig.1B and C). The common melting temperature for all of the MDV dust samples examined was about $87.8{ }^{\circ} \mathrm{C}$. Interestingly, the $\mathrm{C}_{\mathrm{T}}$ values that were obtained did not seem to be dependent on the purity of the DNA used, suggesting that the LAMP assay is resistant to inhibitors present in crude dust samples. Recently, Yoshikawa et al. [28] applied a dry-reagents LAMP assay for the direct detection of human herpesvirus 6B in human serum samples. They found the direct detection system to be a potentially perfect solution for major tropical diseases.
(A)

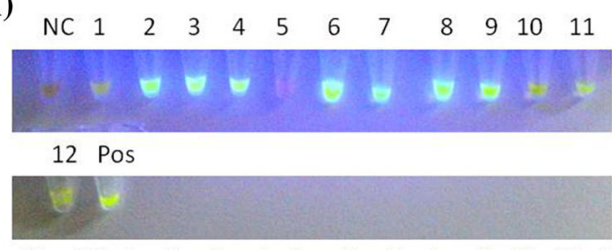

(B)

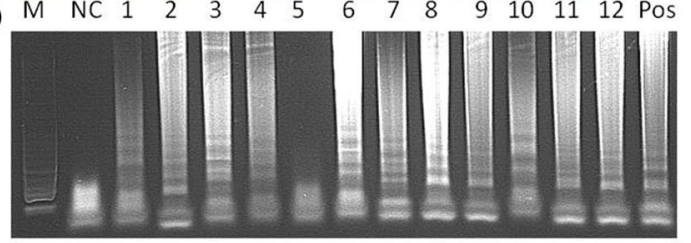

(C)

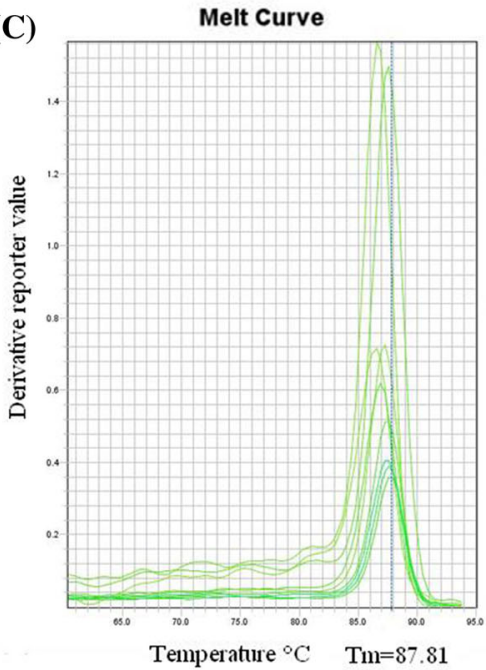

Fig. 1 Direct detection of MDV DNA in poultry farm dust by LAMP. (A) Detection of MDV under UV light illumination after the addition of SYBR Green ${ }^{\circledR}$ I dye, (B) electrophoresis of LAMP products in a $2 \%$ agarose gel stained with GelRed ${ }^{\mathrm{TM}}$ dye (Biotum, Hayward, CA, USA), (C) melting curve analysis of LAMP products conducted in a real-time PCR 7500 system (Applied Biosystems, Foster City, CA, USA). NC, negative control DNA extracted from uninfected SPF chicken embryo fibroblasts (CEF); Pos, positive control DNA of the standard 31/07 vv+MDV strain (accession number: HQ204806.1); 1-12, poultry dust samples collected from potentially MDV-contaminated farms; $\mathrm{M}$, molecular size marker (GeneRuler $^{\mathrm{TM}}$ 100bp DNA Ladder Plus, Thermo-scientific, Waltham, Massachusetts, USA). The common melting temperature point for all LAMP products was $87.8^{\circ} \mathrm{C}$. The derivative reporter value is plotted on the $\mathrm{y}$-axis, whilst the temperature is plotted on the $\mathrm{x}$-axis 
Likewise, Segawa et al. [20] developed a direct LAMPbased detection technique for canine distemper virus (CDV), pseudorabies virus (PRV), feline calicivirus (FCV) and feline parvovirus (FPV) [20]. The authors used a RNA GEM Tissue Kit to extract mammalian DNA and RNA using heat treatment. A similar simplified DNA release method was used to detect Aspergillus nomius and A. flavus from samples of shelled Brazil nuts [14]. In the case of MDV, a good source of viral DNA is poultry dust. PCR and real-time PCR have been widely used for detection, monitoring and modelling of shedding patterns of MDV [2-4, $6,9-12,19,23,24]$. The recently published study by Walkden-Brown et al. [24] showed that all three MDV serotypes could be detected in farm dust using quantitative real-time PCR. They found that $23.1 \%$ of field dust samples contained DNA of MDV-1. The concentration of the extracted DNA was low and reached approximately $5 \mathrm{ng} /$ $\mu \mathrm{L}$, while the median value of the DNA purity reached 0.44 , which supports the results obtained in our study (Table 2). Our results demonstrate the robustness of LAMP for MDV detection, even without DNA purification using crude dust samples. This procedure simplifies monitoring for the presence of MDV under farm conditions when access to laboratory equipment is limited.

In summary, this study shows that the use of simple diagnostic methods including simplified DNA extraction combined with LAMP may aid in the monitoring of chicken farm contamination with MDV. This potentially has an economic aspect, taking into account the high rate of transmission of MDV through poultry dust and the losses caused by MD.

In the future, it would be interesting to extend our study to LAMP detection of the remaining two MDV serotypes and attenuated CVI988/Rispens strains in crude dust samples.

Conflict of interest The authors declare that they have no competing interests.

Open Access This article is distributed under the terms of the Creative Commons Attribution License which permits any use, distribution, and reproduction in any medium, provided the original author(s) and the source are credited.

\section{References}

1. Angamuthu R, Baskaran S, Gopal DR, Devarajan J, Kathaperumal K (2012) Rapid detection of the Marek's disease viral genome in chicken feathers by loop-mediated isothermal amplification. J Clin Microbiol 50:961-965

2. Atkins KE, Read AF, Walkden-Brown SW, Savill NJ, Woolhouse ME (2013) The effectiveness of mass vaccination on Marek's disease virus (MDV) outbreaks and detection within a broiler barn: a modeling study. Epidemics 5:208-217. doi:10.1016/j.epi dem.2013.10.001
3. Baigent SJ, Petherbridge LJ, Howes K, Smith LP, Currie RJ, Nair VK (2005) Absolute quantitation of Marek's disease virus genome copy number in chicken feather and lymphocyte samples using real-time PCR. J Virol Methods 123:53-64

4. Baigent SJ, Smith LP, Currie RJ, Nair VK (2005) Replication kinetics of Marek's disease vaccine virus in feathers and lymphoid tissues using PCR and virus isolation. J Gen Virol 86:2989-2998

5. Baigent SJ, Davison F (2004) Marek's disease virus: biology and life cycle. In: Davidson F, Nair V (eds) Marek's disease: an evolving problem, 1st edn. Elsevier Academic Press, London, pp 62-76

6. Becker Y, Asher Y, Tabor E, Davidson I, Malkinson M, Weisman Y (1992) Polymerase chain reaction for differentiation between pathogenic and non-pathogenic serotype 1 Marek's disease viruses (MDV) and vaccine viruses of MDV-serotypes 2 and 3. J Virol Methods 40:307-322

7. Calnek BW, Adldinger HK, Kahn DE (1970) Feather follicle epithelium: a source of enveloped and infectious cell-free herpesvirus from Marek's disease. Avian Dis 14:219-233

8. Gong Z, Zhang L, Wang J, Chen L, Shan H, Wang Z, Ma H (2013) Isolation and analysis of a very virulent Marek's disease virus strain in China. Virol J 10:155. doi:10.1186/1743-422X-10-155

9. Handberg KJ, Nielsen OL, Jørgenson PH (2001) Use of serotype1- and serotype 3-specific polymerase chain reaction for the detection of Marek's disease virus in chickens. Avian Pathol 30:243-249

10. Islam A, Harrision B, Cheetham BF, Mahony TJ, Young PL, Walkden-Brown SW (2004) Differential amplification and quantitation of Marek's Disease viruses using real-time polymerase chain reaction. J Virol Methods 119:103-113

11. Islam A, Walkden-Brown SW (2007) Quantitative profiling of the shedding rate of the three Marek's disease virus (MDV) serotypes reveals that challenge with virulent MDV markedly increases shedding of vaccinal viruses. J Gen Virol 88:2121-2128

12. Islam T, Renz KG, Walkden-Brown SW, Ralapanawe S (2013) Viral kinetics, shedding profile and transmission of serotype 1 Marek's disease vaccine Rispens/CVI988 in maternal antibodyfree chickens. Avian Dis 57(Suppl. 1):454-463

13. Jurajda V, Klimes B (1970) Presence and survival of Marek's disease agent in dust. Avian Dis 14:188-190

14. Luo J, Taniwaki MH, Iamanaka BT, Vogel RF, Niessen L (2014) Application of loop-mediated isothermal amplification assays for direct identification of pure cultures of Aspergillus flavus, A. nomius, and A. caelatus and for their rapid detection in shelled Brazil nuts. Int J Food Microbiol 172:5-12. doi:10.1016/j.ijfood micro.2013.12.001

15. Morrow C, Fehler F (2004) Marek's disease: a worldwide problem. In: Davidson F, Nair V (eds) Marek's disease: an evolving problem, 1st edn. Elsevier Academic Press, London, pp 49-61

16. Notomi T, Okayama H, Masubuchi H, Yonekawa T, Watanabe K, Amino N, Hase T (2000) Loop-mediated isothermal amplification of DNA. Nucleic Acids Res 28:E63

17. Osterrieder N, Kamil JP, Schumacher D, Tischer BK, Trapp S (2006) Marek's disease virus: from miasma to model. Nat Rev Microbiol 4:283-294

18. Parida M, Posadas G, Inoue S, Hasebe F, Morita K (2004) Realtime reverse transcription loop-mediated isothermal amplification for rapid detection of West Nile Virus. J Clin Microbiol 42:257-263

19. Renz KG, Islam A, Cheetham BF, Walkden-Brown SW (2006) Absolute quantification of Marek's disease virus serotype 2 using real-time polymerase chain reaction in field dust samples, spleens, and feather tips. J Virol Methods 135:186-191

20. Segawa T, Kobayashi Y, Sase Y, Itou T, Suzuki M, Endoh T, Nakanishi T, Sakai T (2014) Easy-to-use rapid gene amplification 
method for direct detection of RNA and DNA viruses in sera and feces from various animals. J Virol Methods. doi:10.1016/j.jvir omet.2014.01.019

21. Venugopal K (2000) Marek's disease: an update on oncogenic mechanisms and control. Res Vet Sci 69:17-23

22. Wajid SJ, Katz ME, Renz KG, Walkden-Brown SW (2013) Prevalence of Marek's disease virus in different chicken populations in Iraq and indicative virulence based on sequence variation in the EcoRI-Q (meq) gene. Avian Dis 57:562-568

23. Walkden-Brown SW, Hunt PW, McNally J, Cressman MD, Burgess SK, Islam AFMF (2013) Development of methods for recovery and quantitation of viral nucleic acids from broiler litter. Proc Aust Poult Sci Symp 24:171-174

24. Walkden-Brown S, Islam A, Groves P, Rubite A, Sharpe S, Burgess S (2013) Development, application and results of routine monitoring of Marek's disease virus in broiler house dust using real-time quantitative PCR. Avian Dis 57(Suppl. 2):544-554
25. Witter RL (1997) Increased virulence of Marek's disease virus field isolates. Avian Dis 41:149-163

26. Woźniakowski GJ, Samorek-Salamonowicz E, Kozdruń W (2011) Rapid detection of Marek's disease virus in feather follicles by loop-mediated amplification (LAMP). Avian Dis 55:462-467

27. Woźniakowski G, Samorek-Salamonowicz E, Kozdruń W (2011) Molecular characteristics of Polish field strains of Marek's disease herpesvirus isolated from vaccinated chickens. Acta Vet Scand 53:10. doi:10.1186/1751-0147-53-10

28. Yoshikawa T, Matsuo T, Kawamura Y, Ohashi M, Yonekawa T, Kanda H, Notomi T, Ihira M (2014) Direct detection of human herpesvirus $6 \mathrm{~B}$ by the LAMP method using newly developed dryreagents. J Virol Methods. doi:10.1016/j.jviromet.2014.02.017 